\title{
APPLYING BLENDED FORESIGHT METHODS FOR REVEALING INCENTIVES AND FUTURE STRATEGIES OF KEY NATIONAL INNOVATION SYSTEM PLAYERS
}

\author{
Alexander Chulok
}

\begin{abstract}
A B S T R A C T
The paper aims to develop and apply a methodological approach that could help to reveal incentives and future strategies of key National Innovation System (NIS) players considering the influence of global social, economic, scientific, technological and ecological trends. To fulfil this aim, a blended foresight methodology was applied, grounded on the platform of economic and classic foresight theory and considering four possible directions for using foresight methods: investigating and building a common vision; supporting evidence-based decisions; promoting communication and participation; inducing transformation and integration into the decision-making process. The main results and findings of the research include a list of 19 global trends, defined from literature analysis and the author's expert knowledge, a short description of their influence on key NIS players, including society, business, infrastructure and institutions, science, education and government; and mapping more than 35 different foresight methods that could be used for revealing incentives and future strategies of key NIS players. The article's theoretical contribution to economic theory consists of several parts. First, a NIS conception is examined through the prism of global trends and a dynamic aspect, whereas it is mostly investigated from statistical and static perspectives. Second, applying foresight as an instrument for researching NIS as a system is a developing academic area with some theoretical gaps, considered in this article by designing a conceptional research framework. Third, blending different foresight methods is always a craft, and the approach applied in this article contributes to it. Finally, the article presents several important trends which will appear in NIS and its key players' transformation in the nearest 5-10 years. From practical implications, this article could be useful for proactive policymakers in the field of science, technology and innovation policy at national and regional levels for designing and providing measures for supporting innovation systems effectively. Foresight practitioners and experts are offered useful, practical ideas of different foresight methods and their possible combinations for everyday activities.
\end{abstract}

KEY WORDS

foresight methods, blended foresight, technological change and its management, national innovation system, global trends, new institutional economics, planning models and policy

10.2478/emj-2021-0038
Corresponding author

Alexander Chulok

National Research University Higher School of Economics (HSE), Russia ORCID 0000-0002-2998-8505 e-mail: achulok@hse.ru

\section{INTRODUCTION}

National Innovation Systems (NIS) will be radically transformed in the nearest future under the influence of global trends, primarily connected with Industry 4.0, widely spread Internet of Things (IoT) and artificial intelligence (AI), total digitalisation and new models of conducting research and innovations which become open, shared, multidiscipline and multicultural (OECD, 2021). Although there are hundreds of theoretical and empirical investigations

Chulok, A. (2021). Applying blended foresight methods for revealing incentives and future strategies of key national innovation system players. Engineering Management in Production and Services, 13(4), 160-173. doi: 10.2478/emj-2021-0038 
and thousands of academic papers describing the current status of NIS in different countries and various aspects, approaches to global trends revealing and assessing their effects, the overall research landscape is still seriously fragmented. Key NIS players - business, science, government, education and society are changing dramatically along with technologies brought by a new technological wave, standards and requirements, such as non-carbon, ESG (environmental, social, and governance) or ethical, face new challenges and opportunities. Their incentives for demand and supply of goods and services shift to new strategies that lead to their repositioning in the NIS conception. Accordingly, the role of NIS is challenging and expanding to become an ecosystem for all participants (Sena et al., 2021), providing more social and inclusive functions, supporting the adaptation to uncertainty as a new reality and forthcoming wild cards (events with low probability, but large-scale effects (Chulok, 2021)), such as the pandemic and its effects, and encouraging the transformation of international and domestic economic, social and technological systems.

A fully-fledged scientific approach that could provide a theoretical framework for all these sophisticated transformations is still in progress, as well as its instrumental part needed for revealing incentives and future strategies of key NIS players from the point of view of global trends. In this respect, the foresight approach has successfully proven its efficiency for identifying global trends and creating a future vision at national, industrial, corporate and regional levels for more than 70 years and within three-thousand projects that were conducted using foresight all over the world (Miles et al., 2017; Andersen et al., 2017; Sarpong \& Meissner, 2018). Once a landscape of global trends is identified, different foresight methods could be blended to create a toolkit for dealing with key NIS players in several directions: investigating and building a common vision; supporting evidencebased decisions; promoting communication and participation, and inducing transformation and integration into the decision-making process.

A research gap to which this article contributes consists of two parts: the methodological part, explaining how the future development of NIS and its players could be investigated and predicted through the prism of global trends and using different foresight methods; and the empirical part, precisely establishing what global trends should be considered and what changes in NIS and its players could be induced. Consequently, more than 35 different foresight meth- ods were mapped for dealing with different NIS players (i.e., representing business, society, science and education) considering 19 global trends.

\section{LITERATURE REVIEW}

Classical works on NIS traditionally refer to research made by Lundvall (1992), Freeman (1995) and Nelson (1993) at the beginning of the 90s of the last century. They set a basic framework of this concept, which lately was enhanced by the contribution of Edquist (1997) and other authors (OECD, 1997). This period in the economic theory was aimed at searching for different competitiveness factors at national, regional and corporate levels, and innovations were widely empirically tested to be one the most important factors along with a country's financial and institutional conditions. Initial approaches to NIS included business, science, education and several stakeholders as key players within rather a linear approach. As this conception became popular in policy-making agendas and more data were gathered, processed and investigated, the framework was moving to a more sophisticated view (Godin, 2007; Lundvall, 2007; Acs et al., 2017; Godin, 2017; Lee et al., 2021). Nowadays, several different approaches and conceptual frameworks of NIS can be distinguished, which are primarily aimed at getting a snapshot of the current status of key players at national and regional levels (Lo et al., 2013; Leydesdorff \& Porto-Gomez, 2019), searching for a new type of players, such as venture funds, start-ups, or industrial associations (Datta et al., 2019), delving deep into the process of knowledge creation and dispatch, including the conception of the so-called triple and quadruple helix (Etzkowitz \& Leydesdorff, 2000; Carayannis \& Campbell, 2009; Leydesdorff, 2012; Carayannis et al., 2018; Maruccia et al., 2020). Some authors include systemic, ecosystemic and dynamic approaches to embrace all NIS changes and transformations, including the Big Data analysis (Dedehayir et al., 2018; Prokop et al., 2021; Sena et al., 2021).

One of the main research questions to be resolved is forecasting possible future NIS visions. This academic landscape is still rare. Some attempts were made by using agent-based and similar models, but they do not provide a full-fledged overview and have several limits and restrictions concerning data and the integration into the decision-making process (Zhangqi et al., 2021; Paredes-Frigolett et al., 2021). On the other hand, foresight as a theoretical and empirical instrument has been widely used to serve very similar 
goals. With a vast history since the start as an expertbased technique for forecasting perspective directions for science and technology development (e.g., applied by RAND in the USA (Georghiou et al., 2008) or Delphi survey in Japan (Zartha et al., 2019)) and the transformation into a very serious and sophisticated methodology that drawn on dozens of different research methods from social sciences, mathematics and econometric modelling, marketing and strategic management and even philosophy and psychology (Georghiou et al., 2008; Sokolov \& Chulok, 2016; Gokhberg et al., 2017; Miles et al., 2017). Foresight could be used for investigating and creating future visions for business, education and scientific organisations, traditional and new industries, cities and regions, nations and even geopolitical unions (Vecchiato \& Roveda, 2014; Rohrbeck et al., 2015; Cagnin et al., 2015; Keller et al., 2015; Piirainen et al., 2017; Do Couto e Silva et al., 2017), i.e., all current NIS players (Georghiou \& Harper, 2011; Andersen, 2014; AguirreBastos \& Weber, 2018). The increase in foresight methods and instruments gave rise to more classifications. Apart from traditional approaches that distinguish qualitative, quantitative and semi-quantitative methods, the most profound include the Foresight Diamond suggested by Popper, who distinguished four knowledge sources, i.e., creativity, evidence, expertise and interaction (Popper, 2008). Later, he upgraded his approach to the S.M.A.R.T. Futures Jigsaw, using five classification indicators: scoping futures, mobilising futures, anticipating futures, recommending futures, and transforming futures (Popper, 2011). Saritas et al. used a systemic approach and created the 7I classification following the key foresight study steps: intelligence, imagination, integration, interpretation, intervention, impact and interaction (Saritas, 2013). This idea is close to what Popper invented during his analysis of the main foresight loop, which includes pre-foresight, recruitment, generation, action and renewal (Popper, 2008). Some authors suggest a "client-oriented" approach to foresight method classification in parallel with business offers: "basic", "optimal", and "professional" (Chulok, 2021). They differ by expenditures, required resources, requirements for expertise and special software, the time of conducting, the granularity and accuracy of results, and provide potential foresight clients with a deep understanding of the pros and cons of each "package", also managing expectations.

In summary of the relevant field of these studies, NIS and foresight conceptions were developed initially to provide decision-makers at national, industrial, corporate and regional levels with relevant information of a future vision and help them set appropriate priorities for their tactic actions in the field of science, technology and innovation. The initial pre-assumption for the first foresight studies in the early $50 \mathrm{~s}-70 \mathrm{~s}$ of the last century was that the future could be predicted or forecasted mostly by mathematical models or within large-scale expert surveys, such as Delphi. Later, as the external environment became more sophisticated, more research instruments and techniques had to be used and elaborated. The basic hypothesis for that period, which is still relevant, was that the future could be formed or designed by stakeholders (e.g., key NIS players) more than forecast by a limited number of highly professional experts. Nowadays, both conceptions admire the complexity and nonlinear linkages between stakeholders and search for a new theoretical and methodological platform for future development. This is somewhat coherent to what can be observed in the economic theory in its recent search for a deeper understanding of economic agent's behaviour, incentives, causality and drivers, and attempts to build linkages between micro-, meso-, and macrolevels. Similar changes occur at a practical level in the field of strategic development and futurism, where some experts warn about the fundamental shift from the so-called VUCA (volatility, uncertainty, complexity, and ambiguity) approach to the BANI conception (brittle, anxious, nonlinear, and incomprehensible). Anyway, in such turbulent theoretical and practical movements, foresight could be nominated as a universal platform or ecosystem to unite them all.

Recent trends in foresight studies include more emphasis on stakeholder mapping and engagement (Saritas, 2013; Miles et al., 2017), deeper integration into the decision-making process (Gheorghiu et al., 2016; Pombo-Juárez, 2017; Minkkinen et al., 2019; Wang \& Li, 2019; Wright et al., 2020; Robinson et al., 2021), increasing future literacy as a capability (Miller et al., 2018), and using a systemic approach to its organisation and conducting (Munigala et al., 2018; Van Dorsser \& Taneja, 2020). These make a realistic idea of applying foresight methods for revealing incentives and future strategies of key NIS players.

Thus, this article answers the following research question: how foresight could be applied for better understanding incentives and future strategies of key NIS players? In search of an answer, conceptional frameworks were elaborated to understand NIS players in light of global trends, create a list of global trends that could influence key NIS players in the nearest future till 2030, and develop four bases of 
applying foresight methods. As a result, 19 global trends were identified, and 35 foresight methods were included in the final matrix (Table 2).

The article contributes to the conceptual bridging of economic theory and practice in the field of technological change, innovations and economic systems. It presents a research methodology that reveals foresight possibilities for investigating NIS future and its key players, provides practical recommendations for decision-makers, including policy-makers for blending and choosing instruments for that, and opens the floor for further discussion.

\section{RESEARCH METHODOLOGY}

Considering the approaches and results of the abovementioned works, the following research design (Fig. 1) and research methodology (Fig. 2) were applied.

Step 1 - identification of key NIS players. Six different stakeholders were distinguished for this article: society, business, infrastructure and institutions, science, education and government. It can be argued that at least twice as many players exist, such as research funds, start-ups, different associations, expert societies and communication platforms that also play an important role in NIS. It is certainly true; however, for this conceptual model, it is enough to examine the created approach and leave some room for further improvements and discussions.
Step 2 - setting global trends - was a challenge due to numerous profound reports, academic papers and research efforts devoted to their analysis. Among the most influential and scientifically proven originated in China, Japan, the UK (Saritas, 2013; Miles et al., 2017) and Russia with S\&T Foresight 2030, containing a detailed description of more than 150 global challenges for seven priority areas, such as ICT, nanotechnologies and new materials, medicine, biotechnology, energy, transport systems, and rational use of natural resources (Sokolov \& Chulok, 2016; Gokhberg et al., 2017). Finally, a list of 19 global social, technological, economic, environmental and political trends were elaborated according to the following system of criteria: a trend should be global, e.g., the influence should go beyond geographical or sectoral borders; sustainable, for at least the nearest 10-15 years; and influential, e.g., has a significant current or potential impact on incentives and strategies of investigated key NIS players (Table 1).

Step 3 - choosing appropriate foresight implementation - was made considering four groups:

Group 1 "Exploring and building common vision" is connected with different foresight instruments that provide insights about the future based on scanning global trends, extracting expert knowledge using various sociological methods and platforms (as technological platforms or wiki portals).

Group 2 "Supporting evidence-based decisions", including innovation and investment strategies and plans, stands upon hard data methods such as statisti-

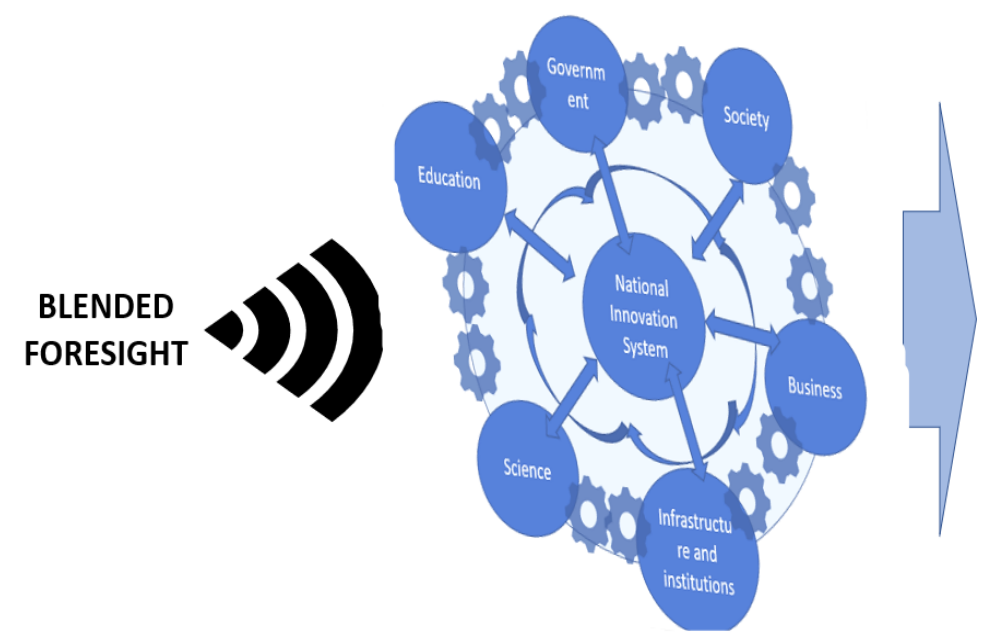

\section{Investigating and building common vision}

Supporting evidence -based decisions

Promoting communication and participation

Inducing transformation and integration into decision-making process

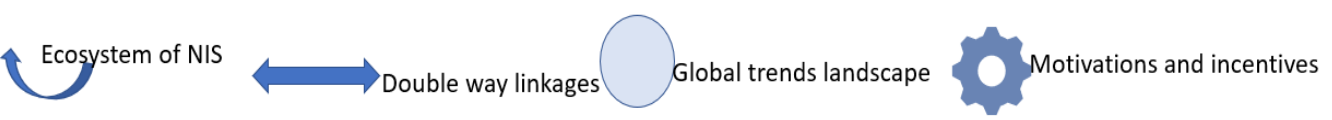

Fig. 1. Conceptual research design framework 
cal, bibliometric or patent analysis, mathematics and econometric modelling on statistical or empirically gathered data, Big Data analytics.

Group 3 "Promoting communication and participation" deals with a huge range of sociological and physiological methods aimed at inducing stakeholder interaction and making it sustainable, using modern IT technologies and opportunities.

Group 4 "Inducing transformation and integration into the decision-making process" is one of the most demanded parts of foresight as it helps to translate results into actions and provides the NIS stakeholder navigation from "point A to point B", applying such instruments as technological and business roadmaps, policy recommendations, scenarios and priorities.

Step 4 - applying a blended foresight for creating a recommendation list for the most efficient methods that could be used for revealing incentives and future strategies of key NIS players by the abovementioned four groups. More than 35 different foresight methods were finally included (Tables 2-7).

\section{RESEARCH RESULTS}

The results of applying the developed methodology to six key NIS players are presented below in the following format: first, a short description of affecting global trends to incentives and strategies is done, and then, the foresight methods divided into four groups are depicted. Some methods are universal, such as STEEPV or scanning for mega- or global trends; however, they differ in their emphasis and estimations concerning a particular NIS player, while others are more bound with a player, such as investigating research fronts for science or citizen panels for society.

Tab. 1. Global trends affecting key NIS players

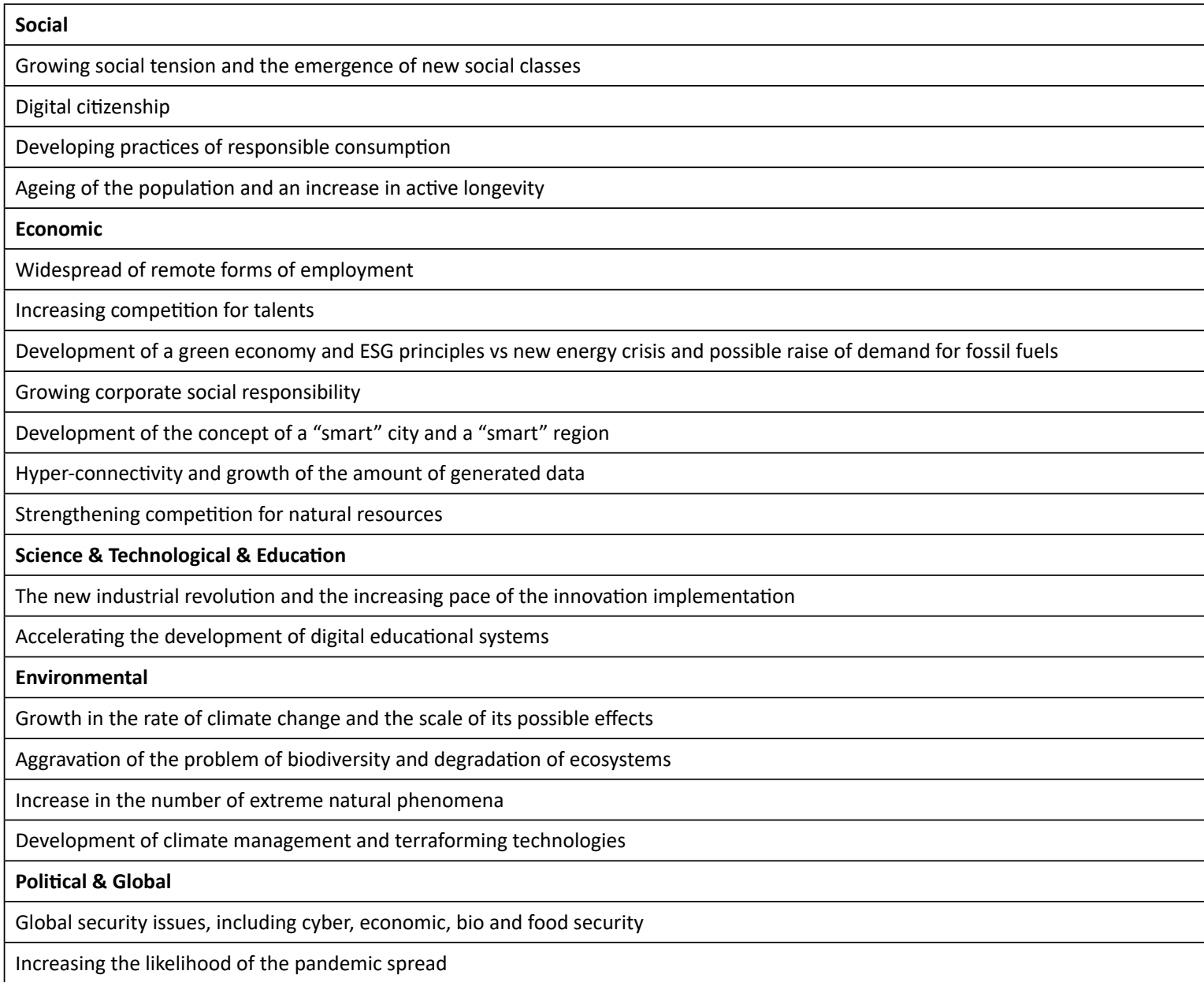

Source: Elaborated by the author based on Chulok et al. (2021). 


Step 1. Identification of key NIS
players
Distinguishing 6 types of stakeholders
Revealing their institutional
design and incentives

\section{Step 4. Applying a blended} foresight

Revealing universal and specific methods for each type of stakeholders

Generalizing research findings

Creating recommendations for foresight methods within 4 groups for each type of stakeholder

Fig. 2. Research methodology: key steps
Step 2. Setting global trends

\section{Creating a list of global trends Estimation their effects on key NIS players}

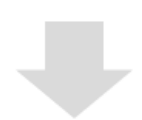

\section{Step 3. Choosing appropriate foresight implementations}

Identifying various foresight methods

Dividing foresight methods into 4 groups

\subsection{SOCIETY}

Global trends encourage society to go digital, age-active, behaviour-responsible and tolerant, increase the requirements for security in a broader sense, and create a resilient and smart envi-ronment, personalised products and services. Human capital plays an increasingly more im-portant role in the technological leapfrog and NIS development as the society's (including HR) perception of innovation and new technologies becomes crucial. Uneven distribution of social classes and demographics, the reduction of response speed and the growing importance of social power and capital require a wide range of foresight instruments focused on revealing the future, inducing personal readiness for transformations, and providing comfortable communication platforms (Table 2).

Societal challenges are becoming more frequently included in agendas of policymakers, NIS and foresight researchers, economics and innovations. The general switch from pure economics and "cost/benefit" principles to the ideas of sustainability induces the application of different methods that help understand society more deeply and broadly (e.g., $\mathrm{AI})$. Businesses are the first wave of NIS players to face this need as companies require elaborate segmentation instruments relevant to at least the current status of their traditional and new consumers. In the nearest future, top-class research in this area could personalise the segmentation approach, literally, to each member of society regardless of age, nationality and other characteristics.

\subsection{BUSINESS}

The fundamental transformation of current business models, widespread in ecosystems, including digital, and encompassing different economic and market aspects (e.g., the economy of trust, the sharing economy, green or non-carbon economics, the silver economy, etc.) in one landscape reveals a real need for using foresight as an efficient instrument for competitive intelligence and forward-looking strategies. Significant reduction in the response time and the need to adjust, and agile, literally, the "online" drive of the business demand for foresight methods mostly connected with the integration into the decision-making process and the creation of proactive systems for strategic analytics, are more frequently based on predictive Big Data analysis and smart recommendation systems (Table 3).

Based on the above, foresight instruments could be divided into several types. The first type is simply adding new techniques and methods to traditional ones, e.g., conducting foresight sessions along with SWOT analysis or creating a BCG matrix. In this case, common results could be enhanced with a low synergy effect. Second, the opposite is more frequently used when modern decision-makers want to update everything. This includes AI, Bid Data analytics, etc. However, without expert validation, even the 
Tab. 2. Applying blended foresight methods: society

\begin{tabular}{|c|c|c|c|}
\hline GROUP 1 & GROUP 2 & GROUP 3 & GROUP 4 \\
\hline $\begin{array}{l}\text { Scanning for megatrends of } \\
\text { social development, cultural } \\
\text { and value transformation } \\
\text { Scanning for global, national } \\
\text { and regional trends connected } \\
\text { with social and demographic } \\
\text { changes } \\
\text { Development of the social } \\
\text { corporate responsibility } \\
\text { Identifying and meeting ESG, } \\
\text { ethics and other requirements } \\
\text { and principles valuable for } \\
\text { society } \\
\text { Creating ecosystems for } \\
\text { boosting demand-driven and } \\
\text { inclusive innovations }\end{array}$ & $\begin{array}{l}\text { Trend watching/environment } \\
\text { scanning/trend monitoring } \\
\text { STEEPVL analysis } \\
\text { Identification of weak signals } \\
\text { and wild cards (WIWE) } \\
\text { connected with society, culture } \\
\text { and values } \\
\text { Stakeholder identification and } \\
\text { mapping } \\
\text { Statistical analysis } \\
\text { Sociological monitoring } \\
\text { and surveys based on } \\
\text { representative samples } \\
\text { Social futurology/ } \\
\text { development of alternative } \\
\text { scenarios }\end{array}$ & $\begin{array}{l}\text { Open events (lectures, } \\
\text { masterclasses, etc.) aimed } \\
\text { at discussing foresight } \\
\text { approaches and results } \\
\text { Citizen panels } \\
\text { Foresight fleet/ marathons/ } \\
\text { hackathons } \\
\text { Creating information signals } \\
\text { for different (relevant) social } \\
\text { groups and stakeholders } \\
\text { Distributing foresight results } \\
\text { using IT platforms and } \\
\text { techniques (inc. mobile } \\
\text { applications) } \\
\text { White papers/memorandums/ } \\
\text { analytical reports } \\
\text { Creating social-oriented } \\
\text { ecosystems and clusters based } \\
\text { on foresight results }\end{array}$ & $\begin{array}{l}\text { Creating different PR strategies } \\
\text { aimed at different (relevant) } \\
\text { social groups and stakeholders } \\
\text { Social responsibility agenda } \\
\text { setting, strategies, and action } \\
\text { plans } \\
\text { Reputation management } \\
\text { including security, } \\
\text { transparency, ESG and ethical } \\
\text { issues }\end{array}$ \\
\hline
\end{tabular}

most profound model or software system only produces more picturesque figures. Third, a truly blended approach refers to fundamental changes to traditional strategic development instruments and their alignment to a complex fully-fledged methodology.

For example, in the Russian S\&T Foresight 2030, to get more interesting and attractive results for the business and to increase their representativeness in the whole research, a methodology was created that combined marketing methods (e.g., the market pull approach, the identification of product and servicecompetitive characteristics) with traditional foresight instruments (e.g., the Delphi survey) and elaborated strategic sessions by adding results of the horizon scanning and stakeholder mapping (Gokhberg et al., 2017).

Nowadays, various businesses actually represent the "living laboratory" for testing different theoretical conceptions. As its role in NIS was changing, the demand for instruments dealing with the future was growing. Russia could be a good example of how a rapid and fundamental transformation could occur. For less than 15 years, Russian companies went from the "no need" position to the "must-have" imperative (Chulok, 2021).

\subsection{INFRASTRUCTURE AND INSTITUTIONS}

Global trends will result in a tremendous infrastructure change in the nearest future: while previously it was mostly physical, many aspects are becoming more digital, such as research and innovation development, generation and dispatching of knowledge, and logistics and supply chains. The cyber-physical embodiment of infrastructure reveals hidden capabilities of key NIS players, including small and medium enterprises, individual research and start-ups, and ensures multinational and multisectoral teams and conducted research, decreases transaction costs and develops transparency. Such changes demand a radical transformation of institutions that should be agile, open to new ideas and their implementation (e.g., within the so-called "sandbox" conception), and provide security in the broad sense, including cyber, product and mental (Table 4).

Infrastructural and institutional challenges become increasingly more crucial for creating the knowledge-based and digital economy and transforming to Industry 4.0 or further. The shortage of resources for the new industrial revolution, including natural, such as silicon for assembling semiconductors, electric energy for cybersports or AI learning, could put the infrastructural question on top. Rigidity and the increasing pace of changes create the demand for a new class of institutions. In this respect, different foresight instruments, such as trend watching and roadmapping could be useful. A good case of how they were applied is "International roadmap for devices and systems ${ }^{\text {tmo", }}$, which unites stakeholders from different countries and elements of value chains and provides a communication platform for designing the future. 
Tab. 3. Applying blended foresight methods: business

\begin{tabular}{|c|c|c|c|}
\hline GROUP 1 & GROUP 2 & GROUP 3 & GROUP 4 \\
\hline $\begin{array}{l}\text { Scanning for megatrends of } \\
\text { markets, consumer patterns } \\
\text { and demand } \\
\text { Scanning for global, national, } \\
\text { regional and industrial trends } \\
\text { Demand segmentation and } \\
\text { searching for new market } \\
\text { niches } \\
\text { Description of prospective } \\
\text { goods and services and } \\
\text { assessment of the timing } \\
\text { of their appearance on the } \\
\text { market } \\
\text { Identification of consumer } \\
\text { characteristics of goods and } \\
\text { services that determine their } \\
\text { future competitiveness } \\
\text { Identification of global and } \\
\text { local value chains and their } \\
\text { promising (high-margin) links } \\
\text { Competitive intelligence/ } \\
\text { identification of competitor's } \\
\text { plans and agendas } \\
\text { Identifying potential cost and } \\
\text { profit centres } \\
\text { New business model's } \\
\text { identification } \\
\text { Boosting demand-driven } \\
\text { innovations } \\
\text { Winner and loser analysis }\end{array}$ & $\begin{array}{l}\text { Trend watching/environment } \\
\text { scanning/trend monitoring, } \\
\text { including business trends } \\
\text { analytics } \\
\text { STEEPVL analysis } \\
\text { Analysis of five market forces } \\
\text { by Porter/ industrial analysis } \\
\text { Competition analysis } \\
\text { Identification of WIWE } \\
\text { Statistical analysis } \\
\text { SWOT analysis } \\
\text { BCG matrix } \\
\text { Developing market scenarios } \\
\text { including market volume and } \\
\text { the CAGR forecast } \\
\text { Delphi survey made by large } \\
\text { expert samples } \\
\text { Empirical surveys made by } \\
\text { representative and statistically } \\
\text { informative samples } \\
\text { Market pull approach } \\
\text { Econometric modelling } \\
\text { Macroeconomic and industrial } \\
\text { models } \\
\text { Product life cycle assessment } \\
\text { Imitation modelling/ } \\
\text { developing scenarios } \\
\text { Predictive analytics, including } \\
\text { IT technologies and Big Data } \\
\text { processing }\end{array}$ & $\begin{array}{l}\text { Foresight-sessions/ industrial } \\
\text { and business sessions aimed at } \\
\text { creating a common vision and } \\
\text { encouraging competitors to } \\
\text { work together } \\
\text { Interactive foresight platforms } \\
\text { Creation of business } \\
\text { ecosystems based on open } \\
\text { innovation principles } \\
\text { Expert panels } \\
\text { White papers and } \\
\text { memorandums }\end{array}$ & $\begin{array}{l}\text { Mid- and long-term strategies } \\
\text { Innovation and investment } \\
\text { planning } \\
\text { Setting priorities } \\
\text { Technological, business and } \\
\text { organisational roadmapping } \\
\text { Win-win action plans } \\
\text { Informing stakeholders and } \\
\text { the CEO }\end{array}$ \\
\hline
\end{tabular}

\subsection{SCIENCE}

An increasing role of STI (science, technology and innovation) in national competitiveness, which was witnessed recently, was boosted by several wildcards - such as the pandemic and low oil prices. Growing expectations of finding Grand Responses for Global Challenges encourage deeper investigations into the nature of STI, all peculiarities of linkages, incentives and motivations inside this framework and create a fruitful discussion on different foresight instrument implementation. Among the most influential is a new wave of modelling and forecasting enhanced by IT technologies. Another important issue is using various communication instruments of foresight: the scientific language always differs from the vocabulary used by other NIS players; thus, translation is essential for a common vision and solution (Table 5).
Initially, foresight was applied for setting STI priorities. Today, its role is expanding and aims to identify research fronts and S\&T frontiers, find areas for mutual collaboration at intercountry, intercultural, and multidiscipline arenas. To fulfil such demands, foresight itself goes to the edge, blending traditional forecast methods, based on statistics and hard data with experts' validation and their tacit knowledge, improving sociological and empirical instruments (e.g., online surveys, including Delphi, which can trace and count the response time) and applying Big Data analytics and AI.

\subsection{EDUCATION}

Education systems all over the world face difficult times caused by pre-pandemic challenges, such as digitalisation, spreading remote education, problems of retraction universities into research and innova- 
Tab. 4. Applying blended foresight methods: infrastructure and institutions

\begin{tabular}{|c|c|c|c|}
\hline GROUP 1 & GROUP 2 & GROUP 3 & GROUP 4 \\
\hline $\begin{array}{l}\text { Scanning for global, national, } \\
\text { regional and industrial trends } \\
\text { in the field of infrastructure } \\
\text { and institutions } \\
\text { Creation of a navigator or atlas } \\
\text { describing different aspects } \\
\text { of the future vision and } \\
\text { demand for infrastructure and } \\
\text { institutions } \\
\text { Identification of the global and } \\
\text { local value and logistics chains }\end{array}$ & $\begin{array}{l}\text { Trend watching/trend } \\
\text { monitoring } \\
\text { Institutional analysis } \\
\text { Statistical analysis } \\
\text { Analysis of goods distributed } \\
\text { within value and logistics } \\
\text { chains based on databases } \\
\text { (e.g., TiVA (Trade in Value- } \\
\text { Added) or WIOD (World Input- } \\
\text { Output Database)) } \\
\text { SWOT analysis } \\
\text { BCG matrix } \\
\text { Benchmarking of suppliers } \\
\text { institutional regimes } \\
\text { Financial and business } \\
\text { modelling } \\
\text { ABC analysis/profit and loss } \\
\text { analysis }\end{array}$ & $\begin{array}{l}\text { Foresight session concentrated } \\
\text { on b2b and b2g segments, } \\
\text { procurement } \\
\text { Creation of ecosystems/ } \\
\text { integration in existing } \\
\text { infrastructural or institutional } \\
\text { ecosystems } \\
\text { Creation and distribution of } \\
\text { informational signals about the } \\
\text { future vision and requests } \\
\text { Engaging education and new } \\
\text { skills for personnel employed } \\
\text { in infrastructure and intuitional } \\
\text { blocks of NIS }\end{array}$ & $\begin{array}{l}\text { Creating a roadmaps action } \\
\text { plan for infrastructure and } \\
\text { institutional part of a common } \\
\text { strategy } \\
\text { Financial and procurement } \\
\text { strategy and action plans } \\
\text { Supply chains management } \\
\text { Changes in risk assessment } \\
\text { models and plans }\end{array}$ \\
\hline
\end{tabular}

Tab. 5. Applying blended foresight methods: science

\begin{tabular}{|c|c|c|c|}
\hline GROUP 1 & GROUP 2 & GROUP 3 & GROUP 4 \\
\hline $\begin{array}{l}\text { Scanning for scientific } \\
\text { megatrends and research } \\
\text { fronts } \\
\text { Scanning for global, national, } \\
\text { regional and industrial trends } \\
\text { with application to scientific } \\
\text { development } \\
\text { Defining characteristics and } \\
\text { effects from radical and } \\
\text { descriptive innovations and } \\
\text { scientific discoveries } \\
\text { Identification of long-term } \\
\text { basic and applied science } \\
\text { problems that can create a } \\
\text { framework for the future } \\
\text { (e.g., teleportation, space } \\
\text { colonisation, nanoassembling) } \\
\text { In-depth interviews }\end{array}$ & $\begin{array}{l}\text { Identification of critical } \\
\text { technologies and developing } \\
\text { their portfolio (leading } \\
\text { countries, centres of } \\
\text { excellence, expenditures, } \\
\text { effects, etc.) } \\
\text { Statistical analysis } \\
\text { Bibliometric and research } \\
\text { fronts analysis including IT } \\
\text { techniques } \\
\text { Patent analysis including } \\
\text { creating patent landscapes } \\
\text { Technological benchmarking } \\
\text { Technological audit } \\
\text { Technology push approach } \\
\text { Delphi surveys } \\
\text { Assessment of technology } \\
\text { readiness level (TRL) } \\
\text { Product life-cycle analysis } \\
\text { Genius forecast (with } \\
\text { prominent researchers and } \\
\text { visionaries, futurologists, } \\
\text { Nobel prize winners etc.) } \\
\text { Futurology/science fiction/ } \\
\text { fantasy/ development of } \\
\text { alternative scenarios } \\
\text { Scientific and technological } \\
\text { WIWE }\end{array}$ & $\begin{array}{l}\text { Foresight session with leading } \\
\text { science experts } \\
\text { Focus groups and private talks } \\
\text { Creation and support of } \\
\text { departments, spinoffs and } \\
\text { start-ups based at universities } \\
\text { Creation of internal } \\
\text { environment for knowledge } \\
\text { and innovation generation, } \\
\text { distribution and circulation } \\
\text { Creation of systems and } \\
\text { ecosystems embracing } \\
\text { scientific and educational } \\
\text { institutions and based on } \\
\text { principles of open science and } \\
\text { innovation }\end{array}$ & $\begin{array}{l}\text { Scientific and technological } \\
\text { roadmap } \\
\text { Creating roadmaps for } \\
\text { interconnection with scientific } \\
\text { organisations and universities } \\
\text { Developing various policy } \\
\text { measures aimed at STI } \\
\text { support, including the "policy } \\
\text { mix" conception } \\
\text { Creating national, industrial } \\
\text { and regional systems for } \\
\text { strategic foresight and } \\
\text { planning and their initialisation } \\
\text { (e.g., via special law or } \\
\text { ministry mandate) }\end{array}$ \\
\hline
\end{tabular}


tions activities and changing society demands for education to be more agile, blended and offer "lighter" formats. After the global lockdown, the "old school" face-to-face communication was recognised as still desirable and live interaction has become a luxury good, but wherein some educational activities went online for a long time, at least to provide life-long learning for everybody. The third mission of universities and expectations from other NIS players open huge possibilities for foresight, especially for setting priorities for the future and creating efficient ecosystems around universities (Table 6).

Pandemic challenges forced fundamental transformation of education as a system, including not only universities and schools but also corporate learning systems and the institute of mentoring. No surprise, education sometimes is more inert than other systems and teachers and students have to pass through endless challenges. Under such conditions, the participative and communicative role of foresight is highly valued. As it stands upon the scientificallybased approach, it is more trusted than other conceptions, and its orientation for designing and forming a common vision is useful. Many world-known universities, such as the University of Manchester, Bialystok University of Technology or National Research University Higher School of Economics, used foresight for developing strategic agendas, educational and STI programmes.

\subsection{GOVERNMENT}

The role of government in establishing and supporting sustainable and efficient NIS was widely discussed since the occurrence of this concept in the mid-90s. Nowadays, the diversification of academic opinions and policy prescriptions differ from pure Adam Smith's invisible hand approach to total intervention into almost all NIS processes. Only time could judge which way was the most efficient, but what is common for all options is the increase of qualified clients among officials, growing demand for evidence-based foresight and policy instruments, interest in scenarios and gamification methods and expanding NIS conception to the ecosystemic approach (Table 7).

The horizon of strategic planning is changing dramatically. Several years ago, almost all foresight and forecasts explored the year 2030 or similar, and now we see a rapid leapfrog to 2050 in the European Policy Agenda (Green Deal 2050), Indonesia Vision 2045, China National Roadmap and Plan 2050, 11th Japan Foresight 2040-2050. To deal with such a long period, which is characterised by exponentially

Tab. 6. Applying blended foresight methods: education

\begin{tabular}{|c|c|c|c|}
\hline GROUP 1 & GROUP 2 & GROUP 3 & GROUP 4 \\
\hline $\begin{array}{l}\text { Scanning for megatrends in } \\
\text { education } \\
\text { Scanning for global, national, } \\
\text { regional and industrial } \\
\text { educational trends } \\
\text { Defining characteristics } \\
\text { and effects from radical } \\
\text { and descriptive innovations } \\
\text { influencing education systems } \\
\text { and universities } \\
\text { Exploring the conception of } \\
\text { the triple and quadruple helix } \\
\text { to clarify the possible vision of } \\
\text { education and universities } \\
\text { Identification of possible } \\
\text { directions for collaboration } \\
\text { with scientific and business } \\
\text { organisation } \\
\text { In-depth interviews }\end{array}$ & $\begin{array}{l}\text { Identification of critical } \\
\text { technologies and developing } \\
\text { their portfolio (leading } \\
\text { countries, centres of } \\
\text { excellence, expenditures, } \\
\text { effects, etc.) } \\
\text { Statistical analysis } \\
\text { Bibliometric and research } \\
\text { fronts analysis including IT } \\
\text { techniques } \\
\text { Patent analysis including } \\
\text { creating patent landscapes }\end{array}$ & $\begin{array}{l}\text { Foresight session with leading } \\
\text { experts in science and } \\
\text { education } \\
\text { Focus groups and private talks } \\
\text { Creation and support of } \\
\text { departments, spinoffs and } \\
\text { start-ups based at universities } \\
\text { Creation of internal } \\
\text { environment for knowledge } \\
\text { and innovation generation, } \\
\text { distribution and circulation } \\
\text { Creation of systems and } \\
\text { ecosystems embracing } \\
\text { scientific and educational } \\
\text { institutions and based on } \\
\text { principles of open science and } \\
\text { innovation } \\
\text { Youth foresight, including } \\
\text { various methods of } \\
\text { communication with pupils } \\
\text { and students (e.g., summer/ } \\
\text { winter schools, seminars, } \\
\text { masterclasses) }\end{array}$ & $\begin{array}{l}\text { Scientific and technological } \\
\text { roadmaps } \\
\text { Creating roadmaps for } \\
\text { interconnection with scientific } \\
\text { organisations and universities } \\
\text { Changes in educational } \\
\text { standards and requirements } \\
\text { due to results of foresight } \\
\text { Educational policy } \\
\text { Developing various policy } \\
\text { measures aimed at STI } \\
\text { support, including the "policy } \\
\text { mix" conception }\end{array}$ \\
\hline
\end{tabular}


increasing uncertainty factors, foresight methods from the creativity group could be useful.

For all these requirements, foresight could suggest reliable instruments, especially in the field of integration into the decision-making process on an everyday basis and creating a fully-fledged foresight system at a national and industrial level as the one developing in Russia (Sokolov \& Chulok, 2016).

Discussion and conclusions

To choose an efficient methodology for working with the future, it is important to understand the peculiarities of demands from key NIS players, which moves toward better quality and in-depth foresight. The most significant trends are the growing demand for more evidence, expanding variability, and the increasing role of priorities.

Evidence implies the existence of a solid scientifically grounded research base, transparent and validated methodology. Arguments "according to experts' estimates" or "the model showed" that satisfied decision-makers 10-15 years ago are no longer considered valid. Variability does not imply a description of the future according to one "base" or "target" scenario, but the characteristic of various alternative scenarios, e.g., simulation modelling or scanning for wild cards. Prioritising means not only ranking the recommendations in the field of markets, products, technologies or science directions. If earlier priorities often came using the "top-down" approach, and then their choice was supported by relevant arguments, now the process is increasingly more "bottom-up": first, a landscape of global trends should be elaborated, and then, depending on the criteria (social or ecological compliance, increase in revenue or marginality, meeting security and safety requirements, etc.) a list of priorities is formed.

The methodological model presented and applied in this article reveals several important trends which will appear in NIS and its key player transformation in the nearest 5-10 years.

Changing the NIS role as a system and its move toward an ecosystem framework, which implies more sophisticated linkages among participants, searching for a balance between manual regulation and free development and deeper integration into solving forthcoming global challenges, primarily connected with the ageing population, energy and climate change, recovery of biodiversity. We notice increasing expectations from NIS stakeholders and especially policymakers for a transformative role of NIS (Havas \& Weber, 2017), which could help economic agents to adapt to the new reality, change business models, mindsets and obtain knowledge and skills needed for deeper integration into the new technological wave.

In this respect, foresight as a visionary basis could be very useful. A shift in academic and empirical research should also include creating or radically updating a statistical system that serviced the NIS conception from the static to the dynamic approach.

Tab. 7. Applying blended foresight methods: government

\begin{tabular}{|c|c|c|c|}
\hline GROUP 1 & GROUP 2 & GROUP 3 & Group 4 \\
\hline $\begin{array}{l}\text { Scanning for megatrends of } \\
\text { geopolitical transformations, } \\
\text { agendas and strategies of } \\
\text { leading innovation counties } \\
\text { and unions } \\
\text { Scanning for global, national } \\
\text { and regional trends connected } \\
\text { with regulation and policies } \\
\text { Setting science, technology } \\
\text { and innovation (STI) priorities } \\
\text { for mid- and long-term } \\
\text { Identification of forks and } \\
\text { alternatives } \\
\text { Stakeholder mapping, } \\
\text { including a description of their } \\
\text { incentives and strategies } \\
\text { In-depth interviews } \\
\text { Identification and description } \\
\text { of key centres of STI excellence }\end{array}$ & $\begin{array}{l}\text { Developing timelines for } \\
\text { regulation and institutional } \\
\text { changes, included in } \\
\text { key strategic documents } \\
\text { (e.g., agenda papers, } \\
\text { memorandums, etc.) } \\
\text { Benchmarking analysis with } \\
\text { other NIS indicators } \\
\text { Statistical analysis of key NIS } \\
\text { indicators } \\
\text { Empirical analysis (including } \\
\text { questionnaire surveys) } \\
\text { Policy scenarios } \\
\text { Imitation models aimed } \\
\text { at assessing effects from } \\
\text { government actions within the } \\
\text { "what if" conception }\end{array}$ & $\begin{array}{l}\text { GR and foresight sessions, } \\
\text { including policymakers } \\
\text { Providing context dialogue } \\
\text { between government and } \\
\text { other NIS players } \\
\text { Exploring possibilities of the } \\
\text { e-government conception } \\
\text { Creating and supporting } \\
\text { institutional and regulatory } \\
\text { framework for developing NIS } \\
\text { and connected ecosystems }\end{array}$ & $\begin{array}{l}\text { National roadmaps and plans } \\
\text { Developing various policy } \\
\text { measures aimed at STI } \\
\text { support, including the "policy } \\
\text { mix" conception } \\
\text { Initiating ad supporting fully- } \\
\text { fledged foresight exercises } \\
\text { Creating national, industrial } \\
\text { and regional systems for } \\
\text { strategic foresight and } \\
\text { planning and their initialisation } \\
\text { (e.g., via special law or ministry } \\
\text { mandate) }\end{array}$ \\
\hline
\end{tabular}


Redistribution of roles between key NIS players and the occurrence of newcomers, such as smart and megacities, regional and innovation clusters, virtual, garage and craft communities. We are witnessing how global trends are affecting incentives and strategies of key NIS players, and they are getting out of the frameworks and boundaries that were efficient in the past. Society becomes more miscellaneous, torn and inclusive, business moves from pure economic agenda to more complex, including social and environmental, infrastructure goes digital, institutions - more vulnerable, science and education face massive canopy of expectations for struggling with new threats and ensuring the development of human capital and government has to embrace these and provide a sustainable, transparent and efficient framework for the future. These innovations require revision of basic NIS conceptions, which have been set up previously, designing or updating the institutional basis. In this respect, foresight as communication and integration platform could be very useful.

Craftmanship of blending foresight methods is becoming increasingly more crucial for supporting the transformation of NIS and its key players. After conducting dozens of foresight projects at international, national, regional and industrial levels and investigating hundreds of similar research efforts all over the world, we can argue that there is no "silver bullet" for a "standard" foresight task. Four groups of possible foresight application types were investigated in this article, and more than 35 different methods were presented, creating a huge landscape of possibilities for further empirical implication and academic discussion on how to apply blended foresight methods for revealing incentives and future strategies of key NIS players applying the global trends approach. The following were the most significant methodological trends. Mutual integration of quantitative and qualitative methods allowing to compensate the disadvantages of one tool with the strengths of others. For example, using the results of mathematical modelling as input information for the work of expert groups and further "manual" verification, considering expert validation about those parameters or relationships that are impossible or difficult to model. Development of multidisciplinary and multicultural research, which allows getting closer to accurate assessment and forecasting of real processes. For example, the assessment of the prospects for the use of new materials in the energy sector or the application of neurobiological approaches to the analysis of the behaviour of economic agents requires the pooling of knowledge from many disparate areas. The widespread use of digital technologies, artificial intelligence, Big Data analysis creates a new class of future research. They can take different forms from visualisation (e.g., using augmented or virtual reality, allowing to get inside a semantic cluster of global trends and study everything in 3D) to predictive analytics based on machine analysis of documents, for which the development of a market consensus forecast is, literally, sense of a momentary matter.

This article contributes to the economic theory in several dimensions. The economic development, rising role of technological, ecological and institution innovations, the increasing pace of technological change and other global trends were embraced in the NIS conception by the theoretical model suggested in the article. To create appropriate recommendations for dealing with the future of six NIS key players, four groups of foresight implementations were suggested. Then, for each NIS player, a mix of foresight methods was elaborated, including universal and specific instruments. Such a methodological approach contributes to the general discussion of economic systems and their development and sets the scene for further enhancement and improvement. In terms of practical contribution, the article improves decision-making at national, industrial and corporate levels as it informs economic agents about precise global trends that can influence their future in the nearest 5-10 years, expands their toolkit for strategic development by suggested foresight instruments, and induces changes and transformations towards the desired vision. Its social impact could be as high as that of global trends, which could affect the society and almost each its member, depict their possible influence on different NIS players and their linkages. For experts and specialists in economic development, innovation, technological change and growth, this article provides a vast landscape for delving deep into the blending of foresight methods.

Future lines of research include conducting a more sophisticated literature review, including the description of cases, providing comparative and narrative analysis, engaging bibliometric software. The discussion of the research findings could be detailed in a separate book as research literature on NIS and foresight is extensive. The same further research could be done with the suggested methodological conception: defining six key NIS players at different levels and broadening their number. Finally, intercountry or intercultural research could be done as NIS is country-specific, and it could be interesting to 
implement the suggested methodology in different counties and then compare results.

\section{ACKNOWLEDGEMENTS}

The article was prepared in the framework of a research grant funded by the Ministry of Science and Higher Education of the Russian Federation (grant ID: 075-15-2020-928). The author would like to express his gratitude to two anonymous Reviewers for useful comments and suggestions.

\section{LITERATURE}

Acs, Z. J., Audretsch, D. B., Lehmann, E. E., \& Licht, G. (2017). National systems of innovation. The Journal of Technology Transfer, 42(5), 997-1008.

Aguirre-Bastos, C., \& Weber, M. K. (2018). Foresight for shaping national innovation systems in developing economies. Technological Forecasting and Social Change, 128, 186-196. doi: 10.1016/j. techfore.2017.11.025

Andersen, A. D., \& Andersen, P. D. (2014). Innovation system foresight. Technological Forecasting and Social Change, 88, 276-286. doi: 10.1016/j. techfore.2014.06.016

Andersen, P. D., Johnston, R., \& Saritas, O. (2017). FTA and Innovation Systems. Technological Forecasting and Social Change, 115, 236-239. doi: 10.1016/j. techfore.2016.12.012

Cagnin, C., Johnston, R., \& Giesecke, S. (2015). Foresight contribution to grand challenges and participative governance in different cultural settings. Technological Forecasting and Social Change, 101, 182-184. doi: 10.1016/j.techfore.2015.11.020

Carayannis, E. G., \& Campbell, D. F. (2009). 'Mode 3' and 'Quadruple Helix': toward a 21st century fractal innovation ecosystem. International Journal of Technology Management, 46, 201-234.

Carayannis, E. G., Grigoroudis, E., Campbell, D. F., Meissner, D., \& Stamati, D. (2018). The ecosystem as helix: an exploratory theory-building study of regional co-opetitive entrepreneurial ecosystems as Quadruple/Quintuple Helix Innovation Models. R\&D Management, 48(1), 148-162.

Chulok, A. A. (2021). 21 Method for dealing with the future in the era of uncertainty. HBR-Russia (in Russian). Retrieved from https://hbr-russia.ru/ biznes-i-obshchestvo/nauka/854793

Datta, S., Saad, M., \& Sarpong, D. (2019). National systems of innovation, innovation niches, and diversity in university systems. Technological Forecasting and Social Change, 143, 27-36. doi: 10.1016/j. techfore.2019.02.005

Dedehayir, O., Mäkinen, S. J., \& Ortt, J. R. (2018). Roles during innovation ecosystem genesis: A literature review. Technological Forecasting and Social Change, 136, 18-29. doi: 10.1016/j.techfore.2016.11.028
Do Couto e Silva, E., Silberglitt, R., Machado, L. C., Maia, J. M. F., \& Cagnin, C. H. (2017). A portfolio analysis methodology to inform innovation policy and foresight. Technological Forecasting and Social Change, 155, 338-347. doi: 10.1016/j.techfore.2016.06.032

Edquist, C. (Ed.). (1997). Systems of Innovation: Technologies, Institutions and Organizations. London, UK: Pinter Publishers/Cassell Academic.

Etzkowitz, H., \& Leydesdorff, L. (2000). The dynamics of innovation: from National Systems and 'Mode 2' to a Triple Helix of university-industry-government relations. Research Policy, 29(2), 109-123.

Freeman, C. (1995). The "National System of Innovation" in historical perspective. Cambridge Journal of Economics, 19(1), 5-24.

Georghiou, L., \& Harper, J. C. (2011). From priority-setting to articulation of demand: foresight for research and innovation policy and strategy. Futures, 43(3), 243251. doi: 10.1016/j.futures.2010.11.003

Georghiou, L., Cassingena, H. J., Keenan, M., Miles, I., \& Popper, R. (Eds). (2008). The handbook of technology foresight: concepts and practice. Edward Elgar: Cheltenham.

Gheorghiu, R., Andreescu, L., \& Curaj, A. (2016). A foresight toolkit for smart specialization and entrepreneurial discovery. Futures, 80, 33-44.

Godin, B. (2007). National Innovation System: The System Approach in Historical Perspective, Project on the History and Sociology of STI Statistics. Working Paper, 36, 34.

Godin, B. (2017). Models of Innovation: The History of an Idea. Cambridge, MA: MIT Press.

Gokhberg, L., Sokolov, A., \& Chulok, A. (2017). Russian S\&T Foresight 2030: Identifying New Drivers Of Growth. Foresight, 19(5), 441-456.

Havas, A., \& Weber, M. K. (2017). The 'fit' between forward-looking activities and the innovation policy governance sub-system: A framework to explore potential impacts. Technological Forecasting and Social Change, 115, 327-337. doi: 10.1016/j. techfore.2016.07.016

Keller, J., Markmann, C., \& von der Gracht, H. A. (2015). Foresight support systems to facilitate regional innovations: A conceptualization case for a German logistics cluster. Technological Forecasting and Social Change, 97, 15-28. doi: 10.1016/j. techfore.2013.12.031

Lee, K., Lee, J., \& Lee, J. (2021). Variety of national innovation systems (NIS) and alternative pathways to growth beyond the middle-income stage: Balanced, imbalanced, catching-up, and trapped NIS. World Development, 144, 105472. doi: 10.1016/j. worlddev.2021.105472

Leydesdorff, L. (2012). The Knowledge-Based Economy and the Triple Helix Model. Amsterdam, Netherlands: University of Amsterdam, Amsterdam School of Communications Research.

Leydesdorff, L., \& Porto-Gomez, I. (2019). Measuring the expected synergy in Spanish regional and national systems of innovation. Journal of Technology Transfer, 44, 189-209. doi: 10.1007/s10961-017-9618-4 
Lo, C.-C., Wang, C.-H., \& Huang, C.-C. (2013). The national innovation system in the Taiwanese photovoltaic industry: A multiple stakeholder perspective. Technological Forecasting and Social Change, 80(5), 893-906. doi: 10.1016/j.techfore.2012.08.016

Lundvall, B. A. (1992). National systems of innovation: Toward a theory of innovation and interactive learning. London, UK: Anthem Press.

Lundvall, B. A. (2007). National Innovation SystemsAnalytical Concept and Development Tool. Industry and Innovation, 14(1), 95119. doi: $10.1080 / 13662710601130863$

Maruccia, Y., Solazzo, G., Del Vecchio, P., \& Passiante, G. (2020). Evidence from Network Analysis application to Innovation Systems and Quintuple Helix. Technological Forecasting and Social Change, 161, 120306. doi: 10.1016/j.techfore.2020.120306

Miles, I., Meissner, D., Vonortas, N. S., \& Carayannis, E. (2017). Technology foresight in Transition. Technological Forecasting \& Social Change, 119, 211-218.

Miller, R. (Ed.). (2018). Transforming the Future: Anticipation in the 21st Century. London, UK: Routledge. doi: 10.4324/9781351048002

Minkkinen, M., Auffermann, B., \& Ahokas, I. (2019). Six foresight frames: Classifying policy foresight processes in foresight systems according to perceived unpredictability and pursued change. Technological Forecasting and Social Change, 149, 119753. doi: 10.1016/j.techfore.2019.119753

Munigala, V., Oinonen, P., \& Ekman, K. (2018). Envisioning future innovative experimental ecosystems through the foresight approach. Case: Design Factory. European Journal of Futures Research, 6, 1.

Nelson, R. R. (1993). National innovation systems: A comparative analysis. Oxford, UK: Oxford University Press.

OECD (1997). National Innovation Systems. Retrieved from https://www.oecd.org/science/inno/2101733.pdf

OECD (2021). OECD Science, Technology and Innovation Outlook 2021: Times of Crisis and Opportunity. Paris, France: OECD Publishing. doi: 10.1787/75f79015-en

Paredes-Frigolett, H., Pyka, A., \& Leoneti, A. B. (2021). On the performance and strategy of innovation systems: A multicriteria group decision analysis approach. Technology in Society, 67, 101632. doi: 0.1016/j. techsoc.2021.101632

Piirainen, K. A., Tanner, A. N., \& Alkærsig, L. (2017). Regional foresight and dynamics of smart specialization: A typology of regional diversification patterns. Technological Forecasting and Social Change, 115, 289-300. doi: 10.1016/j.techfore.2016.06.027

Pombo-Juárez, L., Könnölä, T., Miles, I., Saritas, O., Schartinger, D., Amanatidou, E., \& Giesecke, S. (2017). Wiring up multiple layers of innovation ecosystems: Contemplations from Personal Health Systems. Foresight, Technological Forecasting and Social Change, 115, 278-288. doi: 10.1016/j. techfore.2016.04.018

Popper, R. (2008). Foresight Methodology. In L. Georghiou, J. Cassingena, M. Keenan, I. Miles \& R. Popper (Eds.),
The Handbook of Technology Foresight: Concepts and Practice (pp. 44-88). Cheltenham, UK: Edward Elgar.

Popper, R. (2011). SMART Futures Jigsaw, https:// rafaelpopper.files.wordpress.com/2010/04/ rp_2011_smart-futures-jigsaw.jpg

Prokop, V., Hajek, P., \& Stejskal, J. (2021). Configuration Paths to Efficient National Innovation Ecosystems. Technological Forecasting and Social Change, 168, 120787. doi: 10.1016/j.techfore.2021.120787

Robinson, D. K. R., Schoen, A., Larédo, P., Gallart, J. M., Warnke, P., Kuhlmann, S., \& Ordóñez-Matamoros, G. (2021). Policy lensing of future-oriented strategic intelligence: An experiment connecting foresight with decision making contexts. Technological Forecasting and Social Change, 169, 120803. doi: 10.1016/j.techfore.2021.120803

Rohrbeck, R., Battistella, C., \& Huizingh, E. (2015). Corporate foresight: an emerging field with a rich tradition. Technological Forecasting and Social Change, 101, 1-9. doi: 10.1016/j.techfore.2015.11.002

Saritas, O. (2013). Systemic Foresight Methodology. In D. Meissner et al. (Eds.), Science, Technology and Innovation Policy for the Future (pp. 83-117). Springer.

Sarpong, D., \& Meissner, D. (2018). Special issue on 'corporate foresight and innovation management'. Technology Analysis \& Strategic Management, 30(6), 625-632. doi: 10.1080/09537325.2018.1463934

Sena, V., Arranz, N., Lucas, P., Park, H. W., \& de Arroyabe, J. C. F. (2021). Editorial: Big Data and Network Analysis in National Innovation Systems (NIS). Technological Forecasting and Social Change, 168, 120790. doi: 10.1016/j.techfore.2021.120790

Sokolov, A., \& Chulok, A. (2016). Priorities for future innovation: Russian S\&T Foresight 2030. Futures, 80, 17-32.

Van Dorsser, C., \& Taneja, P. (2020). An integrated threelayered foresight framework. Foresight, 22(2), 250272.

Vecchiato, R., \& Roveda, C. (2014). Foresight for public procurement and regional innovation policy: The case of Lombardy. Research Policy, 43(2), 438-450. doi: 10.1016/j.respol.2013.11.003

Wang, P., \& Li, F. (2019). China's organization and governance of innovation - A policy foresight perspective. Technological Forecasting and Social Change, 146, 304-319. doi: 10.1016/j.techfore.2019.05.029

Wright, D., Stahl, B., \& Hatzakis, T. (2020). Policy scenarios as an instrument for policymakers. Technological Forecasting and Social Change, 154, 119972. doi: 10.1016/j.techfore.2020.119972

Zartha, J., Halal, W., \& Zarta, R. (2019). Delphi method: analysis of rounds, stakeholder and statistical indicators. Foresight, 21, 525-544.

Zhangqi, Z., Zhuli, C., \& Lingyun, H. (2021). Technological innovation, industrial structural change and carbon emission transferring via trade. An agent-based modelling approach. Technovation, 102350. doi: 10.1016/j.technovation.2021.102350 